\title{
History of Specialization in the U.S. Public Accountancy and the CPA Evolution Project
}

\author{
Recep Pekdemir \\ University of Wisconsin La Crosse
}

Ayça Zeynep Süer

Istanbul University

The study has a three-fold purpose. First, it aims to examine the historical developments of the specialization efforts in the accounting profession. Second, a main goal is to review the features of the CPA Evolution that has been a joint project of the NASBA and the AICPA in the U.S. Furthermore, the study attempts to identify and discuss its advantages and disadvantages, challenges, and implications for educators and legislators. The paper argues that the CPA Evolution for the U.S. public accountancy has certain risks and threats, will be emerging initiative and inevitable within the profession, and seems to have formal transforming the CPA licensure.

Keywords: specialization, accounting profession, CPA exam, regulation, accounting education

\section{INTRODUCTION}

Occupations and professions have existed since the early ancient civilizations. Medicine for well-being and long-living of human beings; law, philosophy, sociology for the order of communities and societies; accounting for valuing and recording the possessions of individuals, people, and organizations; such examples can be raised from the ancient history. When human beings started to live in organized social groups of tribes, communities, and societies, reckoning and numeration were needed to track their activities by making marks (Carey, 1969; Littleton, 1933) on stone, clay tablets, and papyrus. Later paper, punched cards, magnetic tapes, hard-disks, nowadays electronic data storage environments such as clouds have replaced. Accounting as occupation and profession had evolved in times and has existed since the early ancient civilizations. A survey of Carmona and Ezzamel (2009) has revealed a remarkably broad arena in which ancient accounting practices of particularly in Mesopotamia and ancient Egypt intervened. They stated different domains of the role of ancient accounting for the state and its institutions such as palaces, tax authorities, state workshops and manufacturing facilities, the religious institutions as small and large temples, private business activities and household.

Public accountancy may refer accounting professionals independently providing services of bookkeeping, preparing statements, auditing and assurance, taxation, and business consulting to the others. It can be argued that there has no existed a general accepted definition of professional or professionalism (Mautz, 1988). However, scientists in the discipline of sociology have agreed on the necessities of four factors for professionalism (Armstrong and Vincent, 1988): Expertise, monopoly, public service, and self- 
regulation that can cover professional code of conducts of the profession (Wilensky, 1964). Carey (1969) distinguished of seven criteria for professions: (1) A body of specialized knowledge, (2) a formal educational process, (3) standards governing admission, (4) a code of ethics, (5) a recognized status indicated by a license or special designation, (6) a public interest in the work that the practitioners perform, (7) recognition by them of a social obligation. Knowledge and expertise are more important for professionalism. Higher education, and training of conceptual and practical are more important for the needed knowledge and expertise as professional competence that should be formally assessed (IFAC-IES, 2019) and certified by professional accounting organizations for recognition or designation of a licensure or certificate. Going back to the last two decades of the $19^{\text {th }}$ Century (Zeff, 2003), CPA licensing in the U.S. had been a major step for the recognition of individuals to practice as public accountants. Having the initial mission of defining moral standards for the accounting history and the U.S. auditing standards, first American Association of Public Accountants (AAPA) was established by the practicing accountants in 1887 (Miranti and Goodman, 1996). In this historical development, it can be mentioned that, due to increased British investments, Scottish and English chartered accountants had gained some credits and recognitions for accountancy in the U.S. (Previts and Merino, 1998). First CPAs had received their licenses in 1896 (Carey, 1969). As a legislation, the first state law enacted in the state of New York on April 17, 1786 to establish the Certified Public Accountant (Magill et al., 1998). The AAPA had renamed several times (Miranti and Goodman, 1996). In 1916, the Institute of Public Accountants succeeded the AAPA, and then named as the American Institute of Accountants (AIA), and finally named as the American Institute of Certified Public Accountants (AICPA) in 1957 (AICPA, 2020a).

Carey (1969) well stated as "economic and social change created the need for an accounting profession - but accountants themselves created the profession by constantly raising their standards of performance, by improving their own education and training, by enlarging the scope of services, and by accepting heavier responsibilities." Not only economic and social changes continued, also innovations and technological developments in many areas have been pervasively expended. Accountants certified or non-certified have been impacted and under-pressured around the world. Especially data management and data analytics have recently become more important for business management. Thus, in 2018, AICPA and National Association of State Boards of Accountancy (NASBA) jointly formed a working group (Tysiac, 2019) to respond developments and changes that have been impacting on public accountancy. The joint project (NASBA AICPA, 2020) is called the CPA Evolution targeting possible changes to the CPA licensure requirements related to the competencies.

The CPA Evolution project has proposed a new model for CPA licensure that is called as "core + disciplines" or simply "core plus." In May 2020, an exposure draft was released to seek possible feedback from stakeholders (Evolution of CPA, 2020). There is no doubt that this would be specialization in the accounting profession. Also, other countries would be following the U.S. practices soon as seen in public oversight establishments on public accountancy.

The study has a three-fold purpose. First, it aims to examine the historical developments of the specialization efforts in the accounting profession. Second, a main goal is to review the features of the CPA Evolution that has been a joint project of the NASBA and the AICPA in the U.S. Furthermore, the study attempts to identify and discuss its advantages and disadvantages, challenges, and implications for educators and legislators. Thus, the study raises and addresses certain questions about the CPA Evolution as follows:

- What is the nature and extend of the new CPA licensure model?

- What might be expected as possible advantages and disadvantages of the initiative?

- Who will be impacted, how and when?

This is a narrative and descriptive study having an intention to contribute to the literature, and to motivate the interested groups to conduct possible empirical or theoretical studies in future.

The paper first examined specializations in the professions, continued to scan specialization efforts in public accounting profession, then reviewed the features of the CPA Evolution project, and attempted to identify and discuss its advantages and disadvantages, challenges, and implications for educators and legislators. 


\section{Specialization in the Professions}

Specialization or branching might be a process of concentrating or focusing on and becoming an expert in a particular subject or skill. Specialization has not been new for some occupations and professions. In medicine for instance, the specialization had been for centuries. Historians agreed that specialization in medicine existed in the Ancient Greece and continued in the Roman Empire (Cartwright, 2013). However, modernized medical specialties emerged gradually in the nineteenth century due to markets' needs and expectations (Weisz, 2003). It can be argued that informal or arbitrary social recognition might has evolved before the formal legal systems in the professions since formalizing and legalizing can later address needs and expectations of society. On the other hand, medical people for example can have different interests and may not have the capacity to handle all diseases that they may not have all skills needed to attain mastery and handle all diseases. In medicine in today's environment, there is no doubt that it can take many years to gain highly specialized skillsets or deep awareness of a human being disease process. In many disciplines, specialization has been non-avoidable so that these arguments and discussions can be extended to many professions including accounting. No individual certified public or chartered accountant can be entirely competent in all areas of accountancy (Riahi-Belkaoui, 2017).

Specialization in the professions has been a necessity since they have been operating in a dynamic environment of the changes. Thus, specialization has been a reality for the professions. Specialization on a de facto basis has been widespread among many professionals in many disciplines. In the accountancy, de facto specialization could be seen for decades all over the world in functional areas such as audit, consulting, taxation, and other services. Needs and expectations of stakeholders such as customers or clients in many fields have forced professionals to provide further specialist services. In some professions, informal or arbitrary social recognition of specialization might not suffice so that formalizing or legalizing might be needed in today's environment. Like others, accounting profession sometimes had some trends and forces that have led toward specialization. There is no doubt that there has been an information explosion in accounting, and there has been an increase in the variety of services demanded from the profession since such concerns have increased over the reliability of financial information.

On the other hand, some additional specialty designations of non-CPA organizations that included the Certified Financial Planner Board of Standards, the Institute of Business Appraisers, the Institute of Internal Auditors, and the Institute of Management Accountants (The Association of Accountants and Financial Professionals in Business) have existed in the U.S for decades.

\section{Specialization Efforts in the U.S. Public Accountancy}

Specialization in the U.S. public accountancy has been on the table as a long debated and controversial issue (Stone, 1968; Davidson, 1970; Barfield, 1974; Graber, 1972, 1973; Hanks, 1979; Siegel, 1977; Olson, 1982; O'Connell and Werner, 1993; Trugman and Person, 1995; Mauldin et al., 2000). Couple initiatives from the late 1950s appeared. However, one can argue that the AICPA had generally been skeptical, reluctant, and less proactive (Chiasson et al., 2006). Until 1981, certified public accountants (CPAs) had been prohibited from using and claiming specialty because the CPAs had already had skills and talents to provide services related to accounting matters. Also, even though specialization in some disciplines such as medicine, law, and others had been effective for the years, it was believed that promoting such specialty areas in accounting profession would be divisive. (Izard and McKinney, 1983; Lambert, 1977).

One of the early efforts toward specialization in the U.S. public accountancy was seen in the early 1960s. In 1961, the AICPA's Ad Hoc Committee on Sections had recommended in five specialty areas of "small businesses, tax, internal management, reporting by public corporations, and reporting by government agencies" (Chiasson et al., 2006). The AICPA Council did not act on this recommendation. Even the AICPA Council reconsidered the concept of specialties, no steps had taken again (Izard and McKinney, 1983; Lambert, 1977). In 1972, revisiting the concept of CPA specialties, the Committee on Scope and Structure was created to study and make recommendation (Lewis, 1989). An exposure draft was prepared by the Committee. Because of these developments, a Special Committee on Specialization was created by the AICPA in 1975; however, no designations as results of the studies realized for specialties were recognized (Chiasson at al., 2006). 
Colorado Society of Certified Public Accountants was first to launch an accreditation program for a specialty designation of the Accredited Personal Financial Specialist (APFS) in 1985 (Shambo and Eveloff, 1993). The AICPA had followed suit and the AICPA Council had formed the Specialization Accreditation Board (SAB) and finally administered first specialization examination in 1987 (Lewis, 1989; Chiasson et al., 2006). This APFS designation was first designation of the AICPA for a specialty and it was changed the Personal Financial Specialist (PFS) in 1992 (Mauldin et al., 2000). A tax specialty designation was discussed again in 1989, then the SAB established a task force to study any possibilities at the matter (Woehlke, 1992). No designation or certification of tax specialty was developed because of that all CPAs presumably are already perceived as having of the tax knowledge needed (Chiasson et al., 2006). However soon after, the AICPA Council approved the AICPA's second specialty designation, the Accredited in Business Valuation (ABV) in 1996 (Beaton and Mard, 2003). And later, the AICPA Council approved the third one as the Certified Information Technology Professional (CITP) in 2000 (Chiasson et al., 2006). This aimed to enhance the quality of information technology services that the AICPA members provide to their customers. In addition to these developments, the AICPA and the Canadian Institute of Chartered Accountants had worked to develop the concept of a new global or international credential (Elliot, 2001). However, the proposal was rejected by the AICPA Council in 2001 (Chiasson et al., 2006).

\section{Position of the International Federation of Accountants (IFAC) and NASBA on Specialization}

Having a broad objective that is to develop and enhance a coordinated worldwide accountancy profession with harmonized high-quality standards, being established in 1977 the IFAC has been an umbrella of the accounting profession organizations or institutes; the AICPA is one of the founding members. The Education Committee of the IFAC had developed and published (IFAC, 1992) a Discussion Paper: Specialization in the Accounting Profession in 1992. This aimed to encourage a dialogue on specialization within and among accounting institutes and organizations. In the discussion paper, specialization was taken to mean the formal recognition by a member institute or organization of a group of accountants possessing distinctive competence in a field or fields of activity of professional accountancy. The discussion paper outlined certain trends and forces that are operating to lead the profession towards specialization, it suggested possible approaches to the question, and discussed possible advantages and disadvantages of formal specialization, its objectives, types, risks, and limits as well (IFAC, 1992).

In 1994, the NASBA had publishes a draft on the State Board Guidelines for Recognitions and Regulation of Specialty Designations that aimed to help the state boards that are willing to do so. The draft had five possible specialty designations of taxation, business and financial services, management consulting, management accounting, and financial planning. Only the State of Florida was willing to get forward on specialization in accounting profession. However, the regulation was taken to the court by Silvia Ibanez who is both lawyer and CPA, and the court decision was against to the regulation (Holstrum, 1998; Calhoun, 1998; John, 1998).

\section{Proposal of Fogarty and Parker}

Fogarty and Parker (2010) argued that accountancy in the U.S. had struggled with the professional image for many years. They stated the CPA designation had been a broad all-purpose brand as an envelope covering all practice areas. The AICPA had created only opportunistic certificates in emerged fields until 2008. Observing specializations in other professions, they argued for the specialization of accounting practice in a more comprehensive and consistent way, and proposed a model that first suggested an umbrella organization as the American Institute of Certified Accountants (AICA), and then sub-institutes of the American Institute of Certified Tax Accountants, the American Institute of Certified Consulting Accountants, the American Institute of Certified Public Accountants, the American Accounting Association, the American Institute of Management Accountants, the American Institute of Certified Forensic Accountants, and the American Institute of Certified Internal Auditors.

It can be argued that the proposed model of Fogarty and Parker was a kind of utopia since many of the sub-institutes suggested have been already existing and leading the world in their fields. Thus, none of those would like to be under the suggested umbrella institute. 


\section{Credentials for More Specialty Designations of the AICPA}

Besides, certificate programs offered in different fields, the AICPA has added four more credentials (AICPA, 2020b) for the designations of specialties recently. Each of those has had its own education and examination requirements. None of those has affected the accounting education program for the U.S. CPA licensure.

\section{Certified in Financial Forensics}

The Certified in Financial Forensics (CFF) that the AICPA introduced in May 2008 as a professional credential needs specialized forensic accounting expertise with core knowledge and skills (Gonzalez, 2010).

\section{Chartered Global Management Accountant}

The Chartered Global Management Accountant (CGMA) designation aims to distinguish professionals who has had an advanced proficiency in finance, operations, strategy, and management. This designation was jointly developed by the AICPA and the Chartered Institute of Management Accountants (CIMA) of the United Kingdom in 2012 (CGMA, 2020). Since then, certified professionals of the CGMA have grown up to 150,000 .

\section{Certified in Entity and Intangible Valuations}

Czaplinski (2017) reported that in 2014 the American Society of Appraisers, the AICPA, the Royal Institution of Chartered Surveyors, some major accounting and valuation firms, and valuation-standard setting organizations came together for a possible collaboration to solve fair value measurement issues. This resulted in the formation of the Fair Value Infrastructure Quality Initiative. The Certified in Entity and Intangible Valuations credential (CEIV) was a result of these endeavors. The CEIV and the Certified in Entity and Intangible Valuations are trademarks of Corporate and Intangibles Valuation Organization, LLC. Both of those have been used under license agreements between the owner and the AICPA (CEIV, 2019).

\section{Certified in the Valuation of Financial Instruments}

The Certified in the Valuation of Financial Instruments (CVFI) credential program was established by the AICPA in 2019 (AICPA, 2019). It aims the AICPA to grant exclusively valuation professionals who can demonstrate experience in fair value estimations for financial reporting.

\section{The CPA Evolution: An Emerging Specialization Project in the U.S.}

The CPA Evolution is a joint initiative and project of the NASBA and the AICPA. It is expected that the CPA Evolution will change and transform the CPA licensure model in the U.S (NASBA, 2019a). In two decades, many developments realized that professions including certified public accountancy have needed to improve skills and competencies (AICPA, 2018). Marketplace where public accountants serve have become more complex rapidly that requires broader knowledge than historically existing, new soft and hard skills and competencies, variety experience as well. Also, it can be observed that public accounting firms have been hiring non-accounting professionals to provide services that market needs (Coffey, 2019). On the other hand, many public accounting services have been provided or delivered by non-accounting professionals all over the world since identifying, measuring, analyzing data, and reporting financial information that has needed more analytics that non-accounting professionals can provide.

Any development and change in any fields of professions can create opportunities and threats for different stakeholders. Whoever is ready to take challenge of the change or development can take the advantages of the opportunities. Whoever is not ready to take will be facing the threats of the change and development. Thus, professionals should have skills set and competencies needed to meet the challenges. For instance, in today's environment, accounting professionals need to have analytical and critical thinking skills, professional judgment and skepticism abilities, problem-solving skills, competencies of understanding business systems, controls, and risks, data analytics and data management knowledge and skills, etc. (NASBA, 2019b). 
The CPA licensure has had three main requirements (3Es) in the U.S.: Education, Examination, and Experience. The CPA Evolution will transform the examination requirement starting from the January 2024. The CPA Evolution is called "a core + discipline licensure model." It will create two-step approach for the examination requirement of the CPA licensure in the U.S. The first step tests knowledge of the candidates in basic fields of accounting, auditing, tax, and information technology. For the second step, candidates will choose one of the three disciplines named as Business Reporting and Analysis, Information Systems and Controls, Tax Compliance and Planning as seen in Figure 1. The names of the disciplines can be evolved and changed depending upon circumstances even before the date of launching the project. At the end of this two-step approach, candidate is to be granted as the CPA in the U.S. There is no doubt many countries will be following the U.S. approach later. It was seen in the public accounting oversight establishment at the beginning of the Millennium.

\section{FIGURE 1 \\ THE CPA EVALUATION: CORE + DISCIPLINE MODEL}

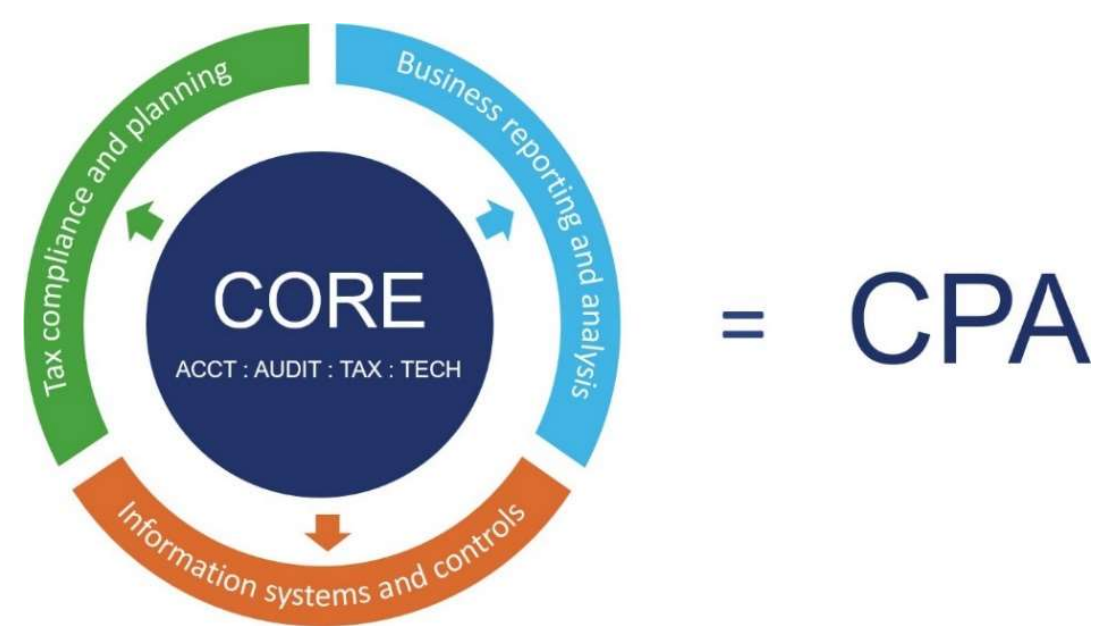

Retrieved October 2, 2020 from https://www.evolutionofcpa.org/

\section{Implications for Educators and Regulators}

There is no doubt that the CPA Evolution will be a major change in the uniform CPA Exam structure for the years.

The CPA Evolution will trigger major changes and developments in accounting education. Higher education institutions, exam prep-institutions, and resource providers will make certain changes in their curriculum, the faculty profile, and the study materials. Most likely certain graduate programs in the three disciplines of the project will pop up soon because there will be a new market for both demand and supply sides.

There is no doubt that the Uniform Accountancy Act Model Rules and state board education requirements in the U.S. will be most likely revised because of the CPA Evolution. Except 150-hour rule commonly existing, there have been varieties for the education requirements of the CPA licensure. It can be argued that these varieties can create such weaknesses that can diminish the public confidence in the CPA qualifications. On the other hand, there has been domestic mobility among the states and jurisdictions even education requirements varieties so this can create less inclination of the possible employers to accept out of state CPA licenses. The CPA Evolution can be a good opportunity to get more uniformed requirements of the $\mathrm{CPA}$ licensure among the states and jurisdictions.

\section{Limitations and Recommendations for Further Studies}

This is a narrative and descriptive study that has limitations. For instance, some quantitative data about the credentials and designations existing in the U.S. public accountancy market. Furthermore, perceptions 
of different stakeholders might have been surveyed about the subject examined in this study. However, we expect to see certain studies about the progress and developments of the CPA Evolution, such as number of enrollments of the disciplines, employment data about the licensed CPAs from different disciplines, market trends of demand and supplies sides for the disciplines that can be subject of empirical or quantitative research studies. On the other hand, some studies can be realized on possible changes that would be seen in accounting education environment not only in higher education institutes also exam prepones.

\section{Summary and Conclusion}

The paper first examined specializations in the professions, then continued to examine the history of the discussions, arguments, initiatives, and developments in the specialty designations in the U.S. public accountancy since the mid of the $20^{\text {th }}$ Century. Financial information users have constantly sought useful information for their investment and lending decisions in financial and money markets globally. Thus, they have expected that useful financial information should have been prepared by experts and competent public accountants. The paper argues that the AICPA has obviously been either reluctant or late to respond or address such market needs and expectations in specializations.

However, the CPA Evolution has been popped up at the end of second decade of the $21^{\text {st }}$ Century due to many reasons. The paper examined the nature and features of the CPA Evolution initiative that is expected to be launched by January 2024. The paper argues that the CPA Evolution can create certain challenges, risks, and threats for some stakeholders besides opportunities for others. It is not certifying of specialty designations in the public accountancy in the U.S.; it is assessing knowledge, skills, and competencies that are related to specialty designations of Business Reporting Analysis, Tax Compliance and Planning, and Information Systems and Controls. There is no doubt that each of those requires specializations in their fields. In our opinion, this will certainly trigger the certification of these disciplines in near future even the AICPA will resist. The model has a goal that the CPA Evolution leads to full CPA license with the same rights and privileges regardless of disciplines. There will be no restrictions for the practice. This is a contradictory for the nature and extend of the market needs and expectations. Possible employers and customers do need to know backgrounds and competencies of the candidates they may hire. Thus, either transcripts of the prior education or the CPA exam components of the job seekers will be sought by the potential employers and customers. This means indirect or hidden specialization in the disciplines of the CPA Evolution.

The riskiest part of this project can be argued that the CPAs passing through one of the disciplines can be categorized as second- or third-class professionals in the market.

\section{REFERENCES}

AICPA. (2018). CPA regulators and profession jointly explore licensure model. Retrieved September 22, 2020, from https://www.aicpa.org/press/pressreleases/2018/cpa-regulators-and-profession-jointlyexplore evolving-licensure.html

AICPA. (2019). CVFI credential handbook - A guide to the AICPA certified in the valuation of financial Instruments credential. Retrieved September 12, 2020, from https://www.aicpa.org/content/dam/

AICPA. (2020a). History of the AICPA. Retrieved September 19, 2020, from https://www.aicpa.org/about/missionandhistory/history-of-theaicpa.html\#: :text=In\%201916\%2C\%20the\%20American\%20Association,Institute $\% 20 \mathrm{of} \% 20 \mathrm{Ce}$ rtified\%20Public\%20Accountants

AICPA. (2020b). Credentials. Retrieved September 23, 2020, from https://www.aicpa.org/membership/join/credentials.html?tab-1=6

aicpa/membership/downloadabledocuments/cvfi-handbook.pdf

Armstrong, M.B., \& Vincent, J.I. (1988). Public accounting: A profession at a crossroads. Accounting Horizons, 2(1), 94. 
Barfield, J.T. (1974). Small firm specialization: Why and how? Journal of Accountancy (pre1986), 137(000006), 58-61.

Beaton, N.J., \& Mard, M.J. (2003). The ABV credential: Leading the way. Journal of Accountancy, 196(6), 41-43.

Calhoun, C. (1998, October). Specialization and regulation in the USA. Education Network, IFAC, 7.

Carey, J.L. (1969). Rise of the accounting profession, v. 1. from technician to professional, 1896-1936.

Retrieved September 3, 2020, from https://egrove.olemiss.edu/aicpa_guides/30/

Carmona, S., \& Ezzamel, M. (2009). Ancient accounting. In J.R. Edwards \& S.P. Walker (Eds.), The Routledge Companion to Accounting History (pp. 73-94). Routledge.

Cartwright, M. (2013, October 26). Roman medicine. In Ancient History Encyclopedia. Retrieved September 19, 2020, from https://www.ancient.eu/Roman Medicine/

CEIV. (2019). Certified in entity and intangible valuations ${ }^{T M}\left(C E I V^{T M}\right)$ credential program handbook.

Retrieved September 8, 2020, from https://ceivsite.files.wordpress.com/2019/08/ceiv-credentialprogram-handbook.pdf

CGMA. (2020). CGMA overview. Retrieved September 10, 2020, from https://www.cgma.org/aboutcgma.html

Chiasson, M., Gaharan, C., \& Mauldin, S. (2006). A history of the development of the AICPA's specialty designation program. The CPA Journal, 76(1), 64-67.

Coffey, S.S. (2019). 5 principles for evolving CPA licensure. Retrieved September 25, 2020, from https://blog.aicpa.org/2019/07/5-principles-for-evolving-cpalicensure.html\#sthash.ZMGEmOPg.dpbs

Czaplinski, N. (2017). The CEIV credential enhances valuation quality, consistency and transparency. Retrieved September 2, 2020, from https://www.accountingtoday.com/opinion/the-ceivcredential-enhances-valuation-quality-consistencyandtransparency\#: : text $=$ The $\% 20$ CEIV $\% 20$ credential $\% 20$ resulted $\% 20$ from $\% 20$ the $\% 20$ Fair $\% 20$ Value $\% 20$ Infrastructure $\% 20$ Quality $\% 20$ Initiative.\&text $=$ The $\% 20$ objective $\% 20$ of $\% 20$ the $\% 20$ cre dential,in\%20valuation\%20methodology\%20and\%20documentation

Davidson, H.J. (1970). Accreditation of CPA specialists. New York Certified Public Accountant (pre1986), 40(000006), 455.

Elliott, R.K. (2001). A perspective on the proposed global professional credential. Accounting Horizons, 15(4), 359-372.

Evolution of CPA. (2020). New model for CPA licensure. Retrieved August 21, 2020, from https://www.evolutionofcpa.org

Fogarty, T.J., \& Parker, L.M. (2010). Reconsidering specialization in the accounting profession: A model for constructive recognition. Journal of Theoretical Accounting Research, 5(2), 1-36.

Gonzalez, A. (2010). Credentials for accountants: Certified in financial forensics. Retrieved September 15,2020 , from https://www.goingconcern.com/credentials-for-accountants-certified-in-financialforensics/

Graber, D.E. (1972). Professional specialization in perspective. Journal of Accountancy (pre-1986), 133(000005), 58-63.

Graber, D.E. (1973). Practitioners forum: SC practitioners' views of professional specialization. Journal of Accountancy (pre-1986), 136(000001), 84-86.

Hanks, G.F. (1979). Formal certification of specialties: A necessary step? The CPA Journal (pre1986), 49(000003), 23-27.

Holstrum, G. (1998, April). Accounting education update - United States. Special Report, Submitted to the Education Committee of the IFAC.

IFAC. (1992, July). Discussion paper: Specialization in the accounting profession. International Federation of Accountants.

IFAC - IES. (2019). Handbook of international education pronouncement. International Accounting Education Standards Board, 2019 Edition. 
Izard, C.D., \& McKinney, J.D. (1983, Fall). The certification of tax specialists: Some empirical results. The Journal of the American Taxation Association, pp. 40-48.

John, C. (1998, October). AICPA adopts market-oriented approach to specialization. Education Network, IFAC, 7.

Lambert, P.E. (1977). Accrediting specialties in public accounting: A logical step. Management Accounting, pp. 19-28.

Lewis, E.C. (1989). Specialization: Have we reached true professional maturity? Accounting Horizons, $3(4), 11-23$.

Littleton, A.C. (1933). Accounting Evolution to 1900. American Institute Publishing Co., Inc. New York.

Magill, H.T., Previts, G.J., \& Robinson, T.R. (1998). The CPA profession: Opportunities, responsibilities, and services. Prentice Hall, New Jersey.

Mauldin, D.S., Wilder, M., \& Stocks, M.H. (2000). Does AICPA accreditation of nonaudit services add value? The case of personal financial planning. Accounting Horizons, 14(1), 49-67.

Mautz, R.K. (1988). Public accounting: Which kind of professionalism. Accounting Horizons, 2(3), 121.

Miranti, J.M., \&Goodman, L. (1996). American Institute of Certified public Accountants. In M. Chatfield \& R. Vangermeersch (Eds.), The History of Accounting: An International Encyclopedia (pp. 3442). Gerland Publishing, Inc. New York \& London.

NASBA. (2019a). Considering the core plus model. Retrieved August 7, 2020, from https://nasba.org/blog/2019/12/19/considering-the-core-plus-model/

NASBA - AICPA. (2020). CPA evolution: New CPA Licensure Model. Retrieved September 20, 2020, from https://www.mecpa.org/writable/news_items/document/cpa_evolution_flyer_july_2020.pdf

NASBA. (2019b). CPA evolution. Retrieved September 17, 2020, from https://www.evolutionofcpa.org/

O'Connel, F.J., \& Werner, B. (1993, May). Point/counterpoint: Tax specialization accreditation. The Tax Advisor, pp. 284-288.

Olson, W.E. (1982). Specialization: Search for a solution. Journal of Accountancy (pre-1986), 154(000003), 70-80.

Previts, G.J., \& Merino, B.D. (1998). A History of accountancy in the United States: The cultural significance of accounting. Ohio State University Press, Columbus.

Riahi-Belkaoui, A. (2017). A profession at a crossroad. SSRN. Retrieved from https://ssrn.com/abstract $=3056392$

Shambo, J., \& Eveloff, S.H. (1993). Is it a good idea to accredit specialists? Journal of Accountancy, $175(4), 41-44$.

Siegel, G. (1977). Specialization and segmentation in accounting profession. Journal of Accountancy, 144(5), 74-80.

Stone, M.L. (1968). Specialization in the accounting profession. Journal of Accountancy (pre-1986), 125(000002), 25.

Trugman, G.R., \& Person, S. (1995). Must small firms specialize to survive? Journal of Accountancy, 179(1), 41-44.

Tysiac, K. (2019). NASBA and AICPA Seek Input on Evolving Licensure Model. Journal of Accountancy News Post.

Weisz, G. (2003). The emergence of medical specialization in the nineteenth century. Bulletin of the History of Medicine, 77(3), 536-575. Retrieved September 21, 2020, from https://muse.jhu.edu/article/46374

Wilensky, H.L. (1964). The professionalism of everyone? American Journal of Sociology, pp. 137-158.

Woehlke, J.A. (1992). Accrediting a tax specialty: Is now the time? The Tax Advisor, 23(11), 767.

Zeff, S.A. (2003). How the US accounting profession got where it is today: Part I. Accounting Horizons, 17(3), 189-205. 